\title{
PERLINDUNGAN KONSUMEN TERHADAP KETIADAAN LABEL HALAL PADA PRODUK FARMASI MENURUT UNDANG-UNDANG NOMOR 33 TAHUN 2014 TENTANG JAMINAN PRODUK HALAL
}

\author{
Hendrian Wulansari \\ (Mahasiswa Fakultas Hukum Universitas Tarumanagara) \\ (Email: hendrianwulans@ gmail.com) \\ Dr. Anna Maria Tri Anggraini, S.H., M.H. \\ (Corresponding Author)
}

(Dosen Tetap Universitas Trisakti, Mengajar Hukum Perlindungan Konsumen di Universitas

Trisakti, Meraih Gelar Sarjana Hukum dan Doktor di Universitas Trisakti)

(Email: anggraini1601@gmail.com)

\begin{abstract}
This study discusses consumer protection against the absence of halal label on pharmaceutical products according to Law No. 33 of 2014 on Halal Product Guarantee. Based on the existing findings that the presence of medicinal products are still many who use materials that are not kosher. Therefore, an effort is needed to provide consumer rights protection to the certification and labeling of halal products. The problem why in the pharmaceutical products are not included halal label? How about consumer protection against pharmaceutical products that do not include halal label? Ingi research method using normative legal research methods. The result data showed that the absence of halal label on pharmaceutical products due to the factors that influence it is because of the difficulty of finding replacement materials for medicines because 90 percent of the drugs are imported from other countries where there is no guarantee of halal. In the near future the producers of drugs are also experiencing constraints because they have to conduct research on raw materials because of the difficulty of the origin of the material also has its own complexity so it takes a long time. On the other hand, the equipment used for the production process, production site, processing, storage, packaging and sales and presentation should be made separately between halal and non-halal certified products / products. Consumer protection against pharmaceutical products that do not include halal labels should have 3 (three) supervisory systems that are preventive by looking at enrollment activities, with special supervision of food cases, medicines and kosher cosmetics that can result in widespread impact and incidental surveillance systems namely the process of supervision by law enforcers on halal food safety and safety done by means of sudden inspection (sidak). There needs to be a systematic joint effort of the government and relevant stakeholders to encourage the maker of halal drug products and raise awareness of the Muslim community about the importance of halal products. It aims to protect Muslims from consuming unlawful products.
\end{abstract}




\section{PENDAHULUAN}

\section{A. Latar Belakang}

Negara Indoesia adalah negara hukum, ${ }^{1}$ yang menjamin perlindungan terhadap seluruh warga negara Indonesia sebagaimana diamanatkan dalam Undang-Undang Dasar Negara Republik Indonesia Tahun 1945 (UUDNRI 1945). Negara juga menjamin kemerdekaan tiap-tiap penduduk untuk memeluk agamanya masing-masing dan untuk beribadah menurut agamanya dan kepercayaannya itu. Untuk menjamin setiap pemeluk agama untuk beribadah dan menjalankan ajaran agamanya, negara berkewajiban memberikan pelindungan dan jaminan tentang kehalalan produk yang dikonsumsi dan digunakan masyarakat selaku konsumen mengingat produk yang beredar di masyarakat belum semua terjamin kehalalannya. ${ }^{2}$ Perlindungan yang diberikan negara terhadap warga negaranya bertujuan untuk memberikan rasa aman dan nyaman dalam menjalani kehidupan berbangsa dan bernegara.

Perlindungan konsumen adalah segala upaya yang menjamin adanya kepastian hukum untuk memberi perlindungan kepada konsumen. ${ }^{3}$ Adapun lingkup jenis dari perlindungan konsumen meliputi barang, jasa, dan atau layanan informasi (iklan) yang akan dan sedang diperdagangkan. ${ }^{4}$ Obat merupakan bahan atau paduan bahan, termasuk produk biologi yang digunakan untuk mempengaruhi atau menyelidiki sistem fisiologi atau keadaan patologi dalam rangka penetapan diagnosis, pencegahan, penyembuhan, pemulihan, peningkatan kesehatan dan kontrasepsi, untuk manusia. ${ }^{5}$ Dengan demikian, ada hubungan yang erat antara perlindungan konsumen dengan kesehatan karena obat-obatan merupakan salah satu jenis barang sebagaimana diatur dalam undang-undang perlindungan konsumen.

\footnotetext{
${ }^{1}$ Undang-Undang Dasar Negara Republik Indonesia Tahun 1945, Pasal 1 Ayat (3).

2 Point menimbang huruf a, b dan c Undang-Undang Nomor 33 Tahun 2014 tentang Jaminan Produk Halal, (Lembaran Negara Tahun 2014 Nomor 295; Tambahan Lembaran Negara Nomor 5604).

${ }^{3}$ Pasal 1 Ayat (1) Undang-Undang Nomor 8 Tahun 1999 tentang Perlindungan Konsumen, (Lembaran Negara Tahun 1999 Nomor 42; Tambahan Lembaran Negara Nomor 3821).

${ }^{4}$ Ibid, Pasal 4, 5, dan 6.

${ }^{5}$ Pasal 1 Ayat (8) Undang-Undang Nomor 36 Tahun 2009 tentang Kesehatan, (Lembaran Negara Tahun 2009 Nomor 144; Tambahan Lembaran Negara Nomor 5063).
} 
Keberadaan industri farmasi telah membantu pemerintah untuk mewujudkan kesehatan masyarakat melalui penyediaan obat yang dibutuhkan di sarana pelayanan kesehatan. Kesehatan merupakan hal yang paling penting dalam kehidupan setiap manusia. Seiring bertambahnya usia, fungsi fisiologis mengalami penurunan akibat proses degeneratif (penuaan) sehingga beragam penyakit muncul pada usia lanjut. Selain itu masalah degeneratif menurunkan daya tahan tubuh sehingga rentan terserang penyakit. ${ }^{6}$

Saat ini banyak beredar produk farmasi di masyarakat yang belum mencantumkan label halal serta belum memproses sertifikat halal untuk produk yang diproduksinya. Status halal dari produk-produk farmasi tengah menjadi perhatian karena akan diberlakukannya sanksi sebagaimana telah diatur dalam Undang-Undang Nomor 33 Tahun 2014 tentang Jaminan Produk Halal. Namun permasalahan muncul karena tidak semua obat-obatan memenuhi syarat untuk berstatus halal. Beberapa di antaranya menggunakan bahan-bahan yang belum masuk kategori halal.

Baru-baru ini telah ditemukannya kasus obat-obatan yang mengandung Deoxyribo Nucleic Acid (DNA) babi yaitu Viostin DS dan Enzyplex oleh Badan Pengawas Obat dan Makanan (BPOM) yang memicu berbagai kontroversi dan keresahan di kalangan masyarakat. Viostin DS yang diproduksi oleh PT Pharos Indonesia sudah beredar di pasaran cukup lama, yang artinya lembaga yang berwenang mengurusi masalah obat-obatan dan makanan (BPOM) telah memberikan surat izin edar. Viostin DS mendapat nomor izin edar oleh BPOM dengan Nomor Edar/NIE POM SD.051523771, Bets BN C6K994H setelah mengajukan sampel ke Laboratorium BPOM dan telah lolos uji oleh Lembaga Pengkajian Pangan, Obat-obatan, Makanan dan Kosmetika Majelis Ulama Indonesia (LPPOM MUI). ${ }^{7}$

${ }^{6}$ Kementerian Kesehatan RI (Tim Redaksi), "Gambaran Kesehatan Lanjut Usia di Indonesia”, Bulitin Jendela Data dan Informasi Kesehatan, Semester I, Tahun 2013, hal.9.

${ }^{7}$ Editorial Team, "Viostin DS dan Enzyplex Lolos Uji LPPOM MUI karena Negatif DNA Babi”, (On-Line), https://kumparan.com/@ kumparanbisnis/viostin-ds-dan-enzyplex-lolos-ujilppom-mui-karena-negatif-dna-babi?ref=rel, (5 Februari 2018). 
Kasus ini terungkap pada pertengahan Januari 2018, beredar luas di media sosial surat dari BPOM Kota Mataram Lombok berisi hasil pengujian sampel suplemen makanan, yaitu Viostin DS dan Enzyplex Tablet yang menyatakan bahwa produk kesehatan Viostin DS dan Enzyplex mengandung DNA Babi. Dalam surat itu ditujukan ke Balai POM di Palangkaraya yang sebelumnya mengirim surat ke Balai BPOM Mataram untuk menguji rujuk sampel kedua produk tersebut. ${ }^{8}$ Selain itu, berdasarkan hasil penelusuran internal, Pharos menemukan salah satu bahan baku pembuatan Viostin DS, yakni chondroitin sulfat yang didatangkan dari pemasok luar negeri dan digunakan untuk produksi bets tertentu, belakangan diketahui mengandung kontaminan. ${ }^{9}$

Meskipun Kepala Badan POM bersama-sama dengan pihak Yayasan Lembaga Konusmen Indonesia (YLKI) dan Lembaga Pengkajian Pangan, Obatobatan, dan Kosmetika Majelis Ulama Indonesia (LPPOM-MUI) sudah menggelar konferensi pers bersama, menindaklanjuti temuan tersebut, namun demikian masih banyak pertanyaan dari masyarakat yang masih belum terjawab. Pada umumnya mereka mempertanyakan tentang keamanan obat dan suplemen yang beredar di masyarakat, terutama terkait dengan status kehalalan dari produkproduk tersebut, mengingat kasus ini bukanlah kasus pertama yang terjadi.

Khusus produk farmasi, periode 31 Desember 2013 tercatat ada 3 (tiga) obat yang mengandung babi yaitu obat yang mengandung heparin molekul rendah, berdasarkan database nomor izin edar yang telah dikeluarkan BPOM. Ketiga obat itu adalah Lovenox Injeksi mengandung Enoxaparin Sodium, didaftarkan oleh PT. Aventis Indonesia, NIE DKI 0185600143A1; Fraxiparin injeksi, mengandung Nadroparin Calcium, didaftarkan oleh PT. Glaxo Welcome Indonesia, NIE DKI 0585100343A1; dan Fuluxum Injeksi, mengandung Parnaparin Sodium, didaftarkan oleh PT. Pratapa Nirmala, NIE DKI 0697600443A1. Kasus-kasus lain yang lebih dahulu mengemuka yaitu

\footnotetext{
${ }^{8}$ Balai Besar Pengawasan Obat dan Makanan Mataram, "Hasil Pengujian Sampel Uji Rujuk Suplemen Makanan”, Mataram, 5 Desember 2017.

9 Ali Mansyur dan Muhammad Nursyamsi, "Ketika Badan POM Kebobolan Produk Mengandung Babi Lagi”, (On-Line) http://www.ihram.co.id/berita/nasional/newsanalysis/18/02/01/p3fkj44-40- ketika-badan-pom-kebobolan-produk-mengandung-babi-lagi, 6 Februari 2018.
} 
yaitu Vaksin Polio (Vaksin Polio Khusus dan Vaksin Polio Oral) tahun 2005 dan Vaksin meningitis pada tahun 2009. ${ }^{10}$

Terkontaminasinya produk-produk farmasi yang mengandung DNA Babi tentu telah meresahkan masyarakat atau konsumen, terkhusus bagi konsumen beragama Islam yang mengedepankan prinsip kehalalan produk. Dalam Islam, Babi atau lemak senyawa yang berasal dari babi haram hukumnya untuk dikonsumsi, ${ }^{11}$ apalagi banyak produk-produk farmasi yang beredar di masyarakat belum semua terjamin kehalalannya. Sementara itu, berbagai peraturan perundang-undangan yang memiliki keterkaitan dengan pengaturan Produk Halal belum memberikan kepastian dan jaminan hukum bagi masyarakat muslim. ${ }^{12}$ Konsumen berhak mendapatkan informasi yang jelas, benar, dan jujur tentang kandungan yang terdapat dalam obat, termasuk apakah obat tersebut mengandung babi atau tidak.

Seperti diketahui bahwa penduduk Indonesia 85\% (delapan puluh lima persen) beragama Islam. ${ }^{13}$ Merujuk pada konstitusi, Pasal 28E ayat (1) dan Pasal 29 ayat (1) dan ayat (2) Undang-Undang Dasar Negara Republik Indonesia 1945 (UUDNRI 1945) mutatis mutandis, Negara menjamin kemerdekaan tiap-tiap penduduk untuk memeluk agamanya masing-masing dan untuk beribadat menurut agamanya dan kepercayaannya itu. Begitu juga dengan penduduk muslim Indonesia, mereka memiliki hak konstitusional untuk memperoleh perlindungan hukum terhadap kehalalan produk sesuai dengan keyakinan agamanya. Oleh karena itu mereka perlu diberi perlindungan hukum berupa jaminan kehalalan pangan yang dikonsumsi dan produk lain yang digunakan.

Pencantuman label halal pada produk makanan, obat-obatan dan kosmetik diatur dalam beberapa peraturan perundang-undangan. Di dalam Pasal 30 ayat (1) Undang-Undang Nomor 7 Tahun 1996 tentang Pangan menyebutkan: "Setiap

${ }^{10}$ Depkes, "Hanya Tiga Jenis Obat Yang Mengandung Babi”, http://www.depkes.go.id/ article/view/2014430001/hanya-tiga-jenis-obat-yang-mengandung-babi-.html, 9 Maret 2018.

11 Abdul Rahman Albaghdadi, Babi Halal, Babi Haram, (Jakarta: Gema Insani Press, 1989), hal. 58.

12 Penjelasan Undang-Undang Nomor 33 Tahun 2014 tentang Jaminan Produk Halal, (Lembaran Negara Tahun 2014 Nomor 295; Tambahan Lembaran Negara Nomor 5604).

${ }^{13}$ Badan Perencana Pembangunan Nasional, Badan Pusat Statistik dan United Nations Populations, Proyeksi Penduduk Indonesia: 2010-2035. (Jakarta: BPS, 2013), hal. 18. 
orang yang memproduksi atau memasukkan kedalam wilayah Indonesia pangan yang dikemas untuk diperdagangkan wajib mencantumkan label pada, di dalam, dan atau di kemasan pangan".

Selanjutnya ayat (2) huruf e, label sebagaiman dimaksudkan ayat (1) memuat sekurang-kurangnya mengenai keterangan tentang halal. Penjelasan tentang pasal 30 ayat (2) huruf e menyebutkan: "Keterangan halal untuk suatu produk pangan sangat penting untuk masyarakat Indonesia yang mayoritas memeluk agama Islam".

Meskipun demikian, pencantumannya pada label pangan baru merupakan kewajiban apabila setiap orang memproduksi pangan dan atau memasukkan pangan ke dalam wilayah Indonesia untuk diperdagangkan, menyatakan bahwa pangan yang bersangkutan adalah halal bagi umat Islam. Adapun keterangan yang dimaksudkan agar masyarakat terhindar dari mengonsumsi pangan yang tidak halal (haram). ${ }^{14}$

Peraturan organik Undang-Undang Nomor 7 Tahun 1996 tentang Pangan, yakni Peraturan Pemerintah Nomor 69 Tahun 1999 tentang Label dan Iklan Pangan, Pasal 10 ayat (1) menyebutkan:

"Setiap orang yang memproduksi atau memasukkan ke dalam wilayah Indonesia pangan yang dikemas untuk diperdagangkan dan menyatakan bahwa pangan tersebut halal bagi umat Islam, bertanggung jawab atas pernyataan tersebut dan wajib mencantumkan keterangan atau tulisan halal pada label".

Selanjutnya di dalam Pasal 11 ayat (1) Peraturan Pemerintah Nomor 69 Tahun 1999 tentang Label dan Iklan Pangan, menyatakan bahwa:

"Untuk mendukung kebenaran pernyataan halal sebagaimana dimaksud dalam Pasal 10 ayat (1), Setiap orang yang memproduksi atau memasukkan ke dalam wilayah Indonesia pangan yang dikemas untuk diperdagangkan wajib memeriksa terlebih dahulu pangan tersebut pada lembaga pemeriksa yang telah diakreditasi atau sesuai dengan peraturan perundang-undangan yang berlaku".

14 Farid Wajdi, "Labelisasi Halal dan Perlindungan Konsumen", http://faridwajdi.com/detailpost/labelisasi-halal-dan-perlindungan-konsumen, (22 Februari 2018). 
Dalam penjelasan Pasal 11 ayat (1) disebutkan bahwa pencantuman tulisan halal pada dasarnya bersifat sukarela. Namun setiap orang yang memproduksi dan memasukkan pangan ke dalam wilayah Indonesia untuk diperdagangkan menyatakan sebagai produk yang halal sesuatu ketuntuan ia wajib mencantumkan ketentuan halal pada label produknya. Selanjutnya dalam penjelasan Pasal 11 ayat (2) menegaskan bahwa lembaga keagamaan dimaksud adalah Majelis Ulama Indonesia (MUI).

Pasal 8 ayat (1) huruf h Undang-Undang Nomor 8 Tahun 1999 tentang Perlindungan Konsumen menegaskan: "Pelaku usaha dilarang memproduksi dan/atau jasa yang tidak mengikuti ketentuan berproduksi secara halal, sebagaimana pernyataan "halal" yang dicantumkan pada label".

Apabila merujuk ketentuan Pasal 4 huruf a dan c Undang-Undang Nomor 8 Tahun 1999 tentang Perlindungan Konsumen, bahwa konsumen berhak atas informasi yang benar, jelas dan jujur mengenai kondisi dan jaminan suatu barang, serta konsumen berhak untuk memilih, perlu diwajibkan sertifikasi yang berisi memberi ruang dan kesempatan bagi kelompok masyarakat yang tidak mengonsumsi barang yang haram termasuk produk-produk farmasi yang jarang sekali mencantumkan label halal dalam setiap kemasannya. Hal yang lebih meresahkan lagi ditemukannya produk farmasi yang mengandung Babi yang secara berulang-ulang pada produk farmasi.

\section{B. Permasalahan}

Berdasarkan uraian latar belakang di atas, maka permasalahan pokok bahasan dalam penelitian ini adalah sebagai berikut:

1. Mengapa dalam produk-produk farmasi tidak disertakan label halal?

2. Bagaimana perlindungan konsumen terhadap produk-produk farmasi yang tidak mencantumkan label halal? 


\section{ANALISIS}

\section{A. Analisis Ketiadaan Label Halal Pada Produk Farmasi}

Dalam Petunjuk Teknis Pedoman Sistem Produksi Halal, Departemen Agama dijelaskan bahwa label halal merupakan pencantuman tulisan atau pernyataan halal pada kemasan produk untuk menunjukkan bahwa produk yang dimaksud berstatus sebagai produk halal. Label halal diperoleh setelah mendapatkan sertifikat halal. Sertifikat halal adalah surat keterangan yang dikeluarkan oleh MUI Pusat atau Provinsi tentang halalnya suatu produk makanan, konsumen muslim dan mengkonsumsi pangan, obat-obatan dan kosmetika yang diproduksi oleh perusahaan setelah diteliti dan dinyatakan halal oleh suatu lembaga yang berwenang menerbitkan sertifikasi produk halal. ${ }^{15}$

Dalam ajaran Islam, diperintahkan mengkonsumsi makanan atau obatobatan yang halal dan baik. Halal dari sisi keagamaan, baik dari sisi kelayakan dan standar kesehatan. Konsep kesehatan dalam Islam tidak hanya mengutamakan kesehatan fisik tetapi juga psikis. Dalam hal menjaga kesehatan, dalam ajaran Islam juga menekankan konsep lebih baik mencegah daripada mengobati karena dengan demikian akan menutup peluang terjadinya akibat buruk atau tindakan preventif atas dampak yang ditimbulkan.

Dengan demikian, dalam perspektif Islam, pencegahan penyakit hukumnya wajib untuk merealisasikan tujuan yang lebih besar, yakni kemaslahatan dan kesehatan yang paripurna. Pencegahan secara dini terhadap kemungkinan terjadinya serangan penyakit salah satu yang dilakukan adalah mengkonsumsi obat-obatan baik untuk pencegahan maupun untuk proses penyembuhan.

Sebagai negara berpenduduk mayoritas Islam, sertifikasi halal pada produk makanan maupun obat-obatan merupakan sebuah kebutuhan untuk menjamin agar tidak mengkonsumsi sesuatu yang haram. Dasar hukum mengkonsumsi makanan yang halal bersumber dari Al-Quran. Begitu pula memperoleh makanan, minuman, serta obat-obatan yang halal sesuai syariat Islam adalah hak bagi setiap

${ }^{15}$ Mashudi, Konstruksi Hukum dan Respons Masyarakat Terhadap Sertifikasi Produk Halal, Cetakan ke-1, (Yogyakarta: Pustaka Pelajar, 2015), hal. 115. 
muslim di manapun. Di Indonesia, hak tersebut jelas-jelas dijamin oleh UndangUndang Dasar 1945. Negara juga menjamin kemerdekaan tiap-tiap penduduk untuk memeluk agamanya masing-masing dan untuk beribadah menurut agamanya dan kepercayaannya itu. Untuk menjamin setiap pemeluk agama untuk beribadah dan menjalankan ajaran agamanya, negara berkewajiban memberikan pelindungan dan jaminan tentang kehalalan produk yang dikonsumsi dan digunakan masyarakat selaku konsumen mengingat produk yang beredar di masyarakat belum semua terjamin kehalalannya, sehingga tidak ada alasan bagi pemerintah untuk tidak melindungi konsumen muslim dalam menjalankan syariat agamanya, termasuk dalam mengkonsumsi obat.

Hubungan agama dan negara di Indonesia dalam penanganan sertifkasi produk halal sebagai dasar hukumnya dapat dilihat dari berbagai ketentuan peraturan perundang-undangan. Di antaranya adalah Undang-Undang Nomor Nomor 7 Tahun 1996 tentang Pangan, Undang-undang Nomor Nomor 8 Tahun 1999 tentang Perlindungan Konsumen dan Peraturan Pemerintah Nomor 69 Tahun 1999 Tentang Label dan Iklan Pangan, serta yang terbaru Undang-undang Nomor 33 tahun 2014 tentang Jaminan Produk Halal (UUJPH).

Apabila ditelaah lebih lanjut, bahwa aturan yang ada dalam UndangUndang Undang-Undang Nomor 7 Tahun 1996 tentang Pangan maupun Peraturan Pemerintah Nomor 69 Tahun 1999 tentang Label dan Iklan Pangan di atas dapat ditarik kesimpulan sebagai berikut:

1. Ketentuan mengenai kehalalan sebuah produk cukup dengan keterangan bahwa produk tersebut halal. Keterangan itu dicantumkan sendiri oleh produsen. Hal itu juga hanya bersifat fakultatif, bukan keharusan.

2. Tidak perlu ada lembaga khusus yang mensertifkasi produk halal. Produsen sendiri yang mencantumkan keterangan halal itu pada produknya.

Selanjutnya UUJPH yang merupakan produk peraturan perundangundangan yang paling kongkrit dan komprehensif mengenai sertifkasi produk halal, karena memang merupakan undang-undang yang secara khusus mengenai masalah tersebut. Keluarnya UUJPH ini dapat dikatakan sebagai era baru penanganan sertifkasi halal di Indonesia. 
Kesadaran akan produk halal sudah menjadi bagian dari kebutuhan kehidupan masyarakat Indonesia yang mayoritas muslim, sehingga sangat mudah untuk menemukan produk halal di Indonesia. Bahkan lebih mudah untuk mendapatkan yang halal dari pada yang haram. Namun di tengah-tengah melimpahnya produk halal, tidak jarang muncul produk halal, terutama yang dihasilkan oleh pabrik modern baik itu makanan, minuman maupun produkproduk obat-obatan. Masyarakat tidak mudah mengenali halal haramnya karena penggunaan bahan baku dan campuran lain, maka orientasi sertifkasi halal di Indonesia didominasi oleh motivasi untuk melindungi masyarakat muslim sendiri.

Akhi-akhir ini masalah produk halal baik itu makanan maupun obat-obatan halal telah menjadi isu global menyusul adanya temuan bahwa beberapa produk olahan terindikasi mengandung bahan baku berasal dari bahan yang tidak halal. Ditemukannya obat-obatan yang mengandung DNA babi pada produk farmasi seperti Vaksin, Viostin DS dan Enzyplex keberadannya cukup meresahkan masyarakat karena dalam pandangan Islam ikhtiar mencari kesembuhan, wajib menggunakan metode yang tidak melanggar syariat dan obat yang digunakan untuk kepentingan pengobatan, wajib menggunakan bahan yang suci dan halal. Penggunaan obat yang berbahan najis dan haram untuk pengobatan hukumnya haram, kecuali memenuhi syarat sebagai berikut: ${ }^{16}$

1. Digunakan pada kondisi keterpaksaan (al-dharurat) yaitu kondisi yang apabila tidak dilakukan dapat menancam jiwa manusia, atau kondisi keterdesakan yang setara dengan kondisi darurat, yaitu kondisi keterdesakan yang apabila tidak dilaksanakan maka akan dapat mengancam eksistensi jiwa manusia di kemudian hari.

2. Belum diketemukan bahan yang halal dan suci,

3. Adanya rekomendasi dari para tenaga medis yang kompeten dan terpercaya bahwa tidak ada obat yang halal.

Ketiadaan label halal pada produk farmasi atau obat-obatan memang menjadi permasalahan tersendiri khususnya bagi konsumen muslim. Dengan tidak

\footnotetext{
${ }^{16}$ Fatwa Majelis Ulama Indonesia Nomor 30 Tahun 2013 tentang Obat dan Pengobatan.
} 
adanya label halal pada obat-obatan secara kejiwaan perasaan hati dan batin konsumen tidak akan tenang karena terbayang-bayang dari keterpurukan akibat produk haram. Penggunaan obat yang tidak jelas status kehalalannya akan menjadikan tubuh pengguna terkontaminasi bahan yang mungkin haram atau najis yang berimplikasi pada ibadah pengguna yaitu tidak sah, berdosa dan sia-sia.

Keberadaan produk obat-obatan yang bereda di pasaran memang banyak yang tidak memiliki label halal. Hal itu diakui oleh Kementerian Agama maupun MUI. Berdasarakan hasil wawancaran dengan Siti Nur Azizah selaku Kasubdit Bina Paham Keagamaan Islam dan Penanganan Konflik (Direktorat Urusan Agama Islam dan Pembinaan Syariah, Direktorat Jenderal Bimbingan Masyarakat Islam), Kementeran Agama bahwa saat ini memang banyak ditemukan produk farmasi yang beredar di pasaran, tidak atau belum dicantumkan label halal. ${ }^{17}$

Data dari LPPOM-MUI menunjukkan belum ada satupun obat yang beredar di Indonesia memiliki sertifikat halal. Tidak diketahui pasti, faktor apa yang menyebabkan produsen obat tidak mengajukan permintaan sertifikasi halal atas produk yang dihasilkan. ${ }^{18}$ LPOM-MUI pada Maret 2018, baru menerima sertifikasi halal untuk kelompok obat-obatan hanya dari tiga perusahaan yaitu PT. Ultra Sakti dengan roduknya Balsem Baljitot, PT. Wahidah Indonesia dengan produknya Minyak But-But dan PT. Simpor Pharma Sdn Bhd dengan produknya EPO 100 mg, Softgel, Felic Acid 5mg Tablet, Beauty Collagen Softhels, Liver Force 70mh Softgels, dan Vitamin D3 100IU Softgels. Sebenarnya ada beberapa produk dalam kelompok obat-obatan yang terdaftar memiliki sertifikat halal. Namun kebanyakan hanya berupa produk cangkang kapsul dan gelatin kapsul. ${ }^{19}$

Ketiadaan label halal pada produk farmasi memang banyak faktor diantaranya, menurut Direktur LPPOM-MUI Lukmanul Hakim, sertifikat halal belum dijadikan sebagai sebuah mandatori atau kewajiban oleh pemerintah,

\footnotetext{
${ }^{17}$ Wawancara dengan Dr. Hj. Siti Nur Azizah, S.H., M.Hum, Kasubdit Bina Paham Keagamaan Islam dan Penanganan Konflik (Direktorat Urusan Agama Islam dan Pembinaan Syariah, Direktorat Jenderal Bimbingan Masyarakat Islam), Kementeran Agama Republik Indonesia, Jakarta, 25 Mei 2018.

${ }^{18}$ Anonim, "Label Halal untuk Obat, Perlukah? (Online), https://lifestyle.kompas.com/read/ 2010/03/31/16204391/label.halal.untuk.obat.perlukah, diakses, 2 Juli 2018.

${ }^{19}$ Majelis Ulama Indonesia, "Halal MUI". Lo.Cit.
} 
sehingga banyak produsen yang mengesampingkan pengurusannya. Jika melihat dari sisi positifnya, sertifikasi halal ini seharusnya dapat dijadikan sebagai upaya produsen dalam memenuhi kepuasan konsumen. Produsen banyak yang melihat bahwa obat ini sesuatu yang darurat jadi mengesampingkan kehalalan. Padahal, jika melihat dari sudut pandang yang lain, tidak semua obat sesuatu yang darurat. $^{20}$

Faktor kesulitan dalam sertifikasi obat-obatan juga dialami MUI. Menurut Lukmanul Hakim, kesulitan tersebut terjadi karena sebagian besar bahan baku obat di Indonesia berasal dari impor. Sekitar 90 persen lebih bahan baku obat di Indonesia adalah impor dan bahan baku obat impor dari negara-negara itu sebagian besar belum mempertimbangkan halal dalam memproduksinya. Artinya ini bukan sekedar masalah teknologi tetapi juga karena pengetahuan dan motivasi produksi halal. Secara ilmu dan teknologi, sangat terbuka kemungkinan memproduksi dengan cara halal. Namun demikian, hampir semua jenis obat di Indonesia memiliki kemungkinan tidak halal. Oleh karena itu, pentingnya sertifikasi halal bagi produk farmasi, sebagai upaya mengidentifikasi unsur obat tersebut sehingga memudahkan konsumen untuk memilih. Untuk obat yang tidak halal dan tidak ada alternatif penggantinya untuk sementara dapat digunakan dengan alasan darurat. ${ }^{21}$

Sulitnya sertifikasi halal pada produk farmasi juga diakui oleh Direktur Jenderal Bina Kefarmasian Maura Linda Sitanggang mengatakan tidak mungkin dalam waktu dekat melakukan sertifikasi halal pada obat-obatan. Formulasi sebuah obat begitu komplek. ${ }^{22}$ Kesulitan asal bahan juga memiliki kompleksitas tersendiri. Dari satu formula (resep) terdiri dari beberapa bahan (terkadang lebih dari 10 bahan baku yang digunakan). Masing-masing bahan baku terkadang dipasok dari beberapa pemasok yang juga punya beberapa pabrik. Agar bisa tersertifikasi halal maka semua bahan yang berasal dari berbagai macam tempat

\footnotetext{
${ }^{20}$ Dea Alvi Soraya, 'Obat Halal di Indonesia Masih Kurang Dari Satu Persen`, https://www. republika.co.id/berita/dunia-islam/islam-nusantara/18/04/17/p7c2oy396-obat-halal-di di-indonesiamasih-kurang-dari-satu-persen, diakses 8 Juni 2018.

21 'LPPOM MUI Akui Kesulitan Sertifikasi Obat-Obatan, http://kominfo.jatimprov.go.id/ $\mathrm{read} / \mathrm{umum} / 37940$, (8 Juni 2018).

${ }^{22}$ Ibid.
} 
tersebut harus bersertifikat halal dan bisa ditelusur serta masing-masing bahan harus terdaftar dan bisa diverifikasi.

Sementara bagi produsen farmasi dalam negeri, membuat produk obat dengan materi dan proses yang halal masih menjadi tantangan besar masa depan yang harus ditaklukkan karena selama ini kebanyakan industri farmasi dalam negeri hanya membuat obat kopi yakni obat yang dibuat dengan meniru formula obat paten milik inovator yang sudah habis masa patennya. Inovasi obat baru yang membutuhkan waktu lama dan modal besar utamanya dilakukan oleh industri farmasi di negara-negara maju yang mayoritas penduduknya bukan muslim, sehingga faktor halal tidak diperhatikan dalam membuat produk obat maupun vaksin.

Selain faktor bahan baku, hal lain yang menjadi tantangan terhadap pelaksanaan sertifikasi halal untuk produk obat ini adalah prosesnya. Baik proses produksi, lokasi produksi, pengolahan, penyimpanan, pengemasan dan penjualan serta penyajiannya. Untuk proses produksi, penyimpanan, distribusi dan pemasaran harus dibuat terpisah antara bahan/produk yang sudah bersertifikat halal dan non-halal. Produsen/industri farmasi harus memiliki fasilitas khusus (dedicated), termasuk mesin, peralatan, fasilitas, dan lain-lain. Hal ini tentu akan menyulitkan bagi industri untuk bisa memenuhi persyaratan sertifikasi halal tersebut.

Dengan demikian, ada 2 (dua) hal yang harus diperhatikan, yaitu : (1) Bahan, termasuk bahan baku, bahan olahan, bahan tambahan dan bahan penolong. (2) Prosesnya, baik proses produksi, lokasi produksi, pengolahan, penyimpanan, pengemasan dan penjualan serta penyajiannya. Kedua hal tersebut harus memenuhi syarat syar'i agar bisa memperoleh sertifikat halal.

Dari adanya hal tersebut, pemerintah mengakomodir keinginan umat Islam tentang adanya jaminan produk halal dengan mengundangkan UUJPH. Berdasarkan Pasal 64 UUJPH, dibentuklah Badan Penyelenggara Jaminan Produk Halal (BPJPH) yang telah diresmikan oleh Menteri Agama pada tanggal 11 Oktober 2017. BPJPH adalah badan pemerintah yang ditugaskan untuk menyelenggarakan jaminan produk halal. Keberadaannya berada di bawah 
Kementrian Agama dan bertanggungjawab kepada menteri juga. Menurut Pasal 6 UUJPH, kewenangan BPJPH dalam menyelenggarakan jaminan produk halal mencakup:

(a) merumuskan dan menetapkan kebijakan JPH;

(b) menetapkan norma, standar, prosedur, dan kriteria JPH;

(c) menerbitkan dan mencabut Sertifikat Halal dan Label Halal pada Produk;

(d) melakukan registrasi Sertifikat Halal pada produk luar negeri;

(e) melakukan sosialisasi, edukasi, dan publikasi Produk Halal;

(f) melakukan akreditasi terhadap LPH;

(g) melakukan registrasi Auditor Halal;

(h) melakukan pengawasan terhadap JPH;

(i) melakukan pembinaan Auditor Halal; dan

(j) melakukan kerja sama dengan lembaga dalam dan luar negeri di bidang penyelenggaraan JPH.

Berdasarkan kewenangan atributif di atas, saat ini BPJPH merupakan satusatunya lembaga yang berwenang untuk menyelenggarakan sertifikasi produk halal di Indonesia. Dengan demikian maka proses sertifikasi produk halal tidak lagi berada di bawah kewenangan (LPPOM MUI). Meski demikian, sesuai dengan UUJPH, MUI tetap mempunyai peran strategis dalam proses sertifikasi produk halal. Hal ini menunjukkan bahwa BPJPH dapat melakukan kerjasama dengan MUI terkait proses sertifikasi auditor halal, akreditasi Lembaga Penjamin Halal (LPH) dan penetapan kehalalan produk dalam bentuk fatwa.

Dengan demikian dapat dikatakan bahwa status kehalalan suatu produk dinyatakan dalam bentuk Sertifikat Halal yang dikeluarkan oleh BPJPH berdasarkan fatwa halal dari MU). Dalam melaksanakan wewenang tersebut, BPJPH bekerja sama dengan kementerian atau lembaga terkait, Lembaga Pemeriksa Halal (LPH), dan MUI.

Keberadaan BPJPH dalam proses sertifikasi halal akan lebih efektif karena secara kelembagaan dan legalitas tentunya keberadaan BPJPH menjadi jelas 
karena telah diatur dalam UUJP dan berada di bawah Kementerian Agama. Selain itu, pengurusan proses penyelenggaraan jaminan halal menjadi semakin lebih baik karena ada koordinasi dengan MUI. Mengingat potensi industri halal di Indonesia sangat besar, maka untuk meningkatkan pelayanan sertifikasi dan pengawasan terhadap produk halal maka diharapkan $\mathrm{BPJH}$ dapat beroperasi secara profesionalisme, berintegritas dan transparansi, sehingga terhindar dari pungutan liar dan gratifikasi. Mengingat Indonesia sebagai negara dengan mayoritas Muslim, maka tentunya kebutuhan akan sertifikasi halal atas suatu produk menjadi tinggi, karena dalam perspektif Islam, selain halal makanan juga harus baik (thoyyib). Sebelum dikeluarkannya UU-JPH penyelenggaraan sertifikasi produk halal hanya bersifat voluntary (sukarela), namun demikian setelah diundangkannya UU-JPH, penyelengggaraan sertifikasi halal bersifat mandatory (wajib). Oleh sebab itu, para pelaku usaha memiliki kewajiban untuk mendaftar ke BPJPH agar produknya bisa disertifikasi kehalalannya.

\section{B. Perlindungan Konsumen Terhadap Produk-Produk Farmasi Yang Tidak Mencantumkan Label Halal}

Pada hakekatnya, terdapat dua instrumen hukum penting yang menjadi landasan kebijakan perlindungan konsumen di Indonesia, yakni Undang-Undang Dasar 1945, sebagai sumber dari segala sumber hukum di Indonesia, mengamanatkan bahwa pembangunan nasional bertujuan untuk mewujudkan masyarakat adil dan makmur. Tujuan pembangunan nasional diwujudkan melalui sistem pembangunan ekonomi yang demokratis sehingga mampu menumbuhkan dan mengembangkan dunia yang memproduksi barang dan jasa yang layak dikonsumsi oleh masyarakat. Undang-Undang Nomor 8 Tahun 1999 tentang Perlindungan Konsumen (UUPK). Lahirnya Undang-undang ini memberikan harapan bagi masyarakat Indonesia, untuk memperoleh perlindungan atas kerugian yang diderita atas transaksi suatu barang dan jasa. UUPK menjamin adanya kepastian hukum bagi konsumen.

Sesuai dengan Pasal 3 UUPK, tujuan dari perlindungan konsumen adalah meningkatkan kesadaran, kemampuan dan kemandirian konsumen untuk 
melindungi diri, mengangkat harkat dan martabat konsumen dengan cara menghindarkannya dari ekses negatif pemakaian barang dan/atau jasa, meningkatkan pemberdayaan konsumen dalam memilih, menentukan dan menuntut hak-haknya sebagai konsumen, menciptakan sistem perlindungan konsumen yang mengandung unsur kepastian hukum dan keterbukaan informasi serta akses untuk mendapatkan informasi, menumbuhkan kesadaran pelaku usaha mengenai pentingnya perlindungan konsumen sehingga tumbuh sikap yang jujur dan bertanggungjawab dalam berusaha, meningkatkan kualitas barang dan/atau jasa yang menjamin kelangsungan usaha produksi barang dan/atau jasa, kesehatan, kenyamanan, keamanan dan keselamatan konsumen.

Seperti diketahui bahwa sesuai dengan UUJPH, yang menegaskan bahwa semua produk yang masuk, beredar, dan diperdagangkan di wilayah Indonesia wajib "bersertifikat Halal". Produk yang dimaksud dalam UndangUndang ini adalah barang dan/atau jasa yang terkait dengan makanan, minuman, obat, kosmetik, produk kimiawi, produk biologi, produk rekayasa genetik, serta barang gunaan yang dipakai, digunakan, atau dimanfaatkan oleh masyarakat, termasuk produk yang diimport dari Luar Negeri. Sesuai dengan amanat UU tersebut, maka paling lama 5 tahun sejak diundangkan (UUJPH diundangkan pada tahun 2014) yaitu pada tanggal 17 Oktober 2019, maka seluruh produk yang beredar di Indonesia harus bersertifikat halal, termasuk produk obat dan Suplemen Makanan.

Menurut data dari Badan POM, saat ini terdapat lebih dari 16.000 produk obat dan suplemen makanan yang beredar di masyarakat. Namun dari data LPPOM MUI, tidak lebih dari 100 item $(<0,6 \%)$ obat dan suplemen makanan yang telah bersertifikat halal. Artinya masih ada lebih dari $99 \%$ produk obat dan suplemen makanan yang belum bersertifikat Halal. Tentu ini menjadi perhatian semua pihak untuk duduk bersama agar upaya perlindungan masyarakat melalui Undang-undang Jaminan Halal Produk bisa juga mencakup produk Obat dan Suplemen Makanan. Pemerintah dan regulator, dalam hal ini Departemen Agama, LPPOM MUI dan Badan POM tidak boleh menutup mata terhadap kondisi ini. Perlu ada tindakan segera dari pemerintah agar masyarakat yang saat ini 
kebingunan karena informasi yang disampaikan sangat tidak transparan dan cenderung saling lempar tanggung jawab antar lembaga.

Telah beberapa kali ditemukan obat-obatan yang mengandung DNA Babi yang cukup meresahkan masyarakat. Khusus produk farmasi, periode 31 Desember 2013 tercatat ada 3 (tiga) obat yang mengandung babi yaitu obat yang mengandung heparin molekul rendah, berdasarkan database nomor izin edar yang telah dikeluarkan BPOM. Ketiga obat itu adalah Lovenox Injeksi mengandung Enoxaparin Sodium, didaftarkan oleh PT. Aventis Indonesia, NIE DKI 0185600143A1; Fraxiparin injeksi, mengandung Nadroparin Calcium, didaftarkan oleh PT. Glaxo Welcome Indonesia, NIE DKI 0585100343A1; dan Fuluxum Injeksi, mengandung Parnaparin Sodium, didaftarkan oleh PT. Pratapa Nirmala, NIE DKI 0697600443A1. Kasus-kasus lain yang lebih dahulu mengemuka yaitu yaitu Vaksin Polio (Vaksin Polio Khusus dan Vaksin Polio Oral) tahun 2005 dan Vaksin meningitis pada tahun 2009. Awal tahun 2018 beredar produk obat-obatan yang mengandung Deoxyribo Nucleic Acid (DNA) babi yaitu Viostin DS dan Enzyplex oleh Badan Pengawas Obat dan Makanan (BPOM). Viostin DS mendapat nomor izin edar oleh BPOM dengan Nomor Edar/NIE POM SD.051523771, Bets BN C6K994H setelah mengajukan sampel ke Laboratorium BPOM dan telah lolos uji oleh Lembaga Pengkajian Pangan, Obat-obatan, Makanan dan Kosmetika Majelis Ulama Indonesia (LPPOM MUI).

Berdasarkan temuan-temuan tersebut menunjukkan bahwa keberadaan produk obat-obatan masih banyak yang menggunakan bahan-bahan yang tidak halal. Oleh karena itu, diperlukan suatu upaya untuk memberikan perlindungan hak konsumen terhadap sertifikasi dan labelisasi produk halal pada produk obatobatan harus senantiasa diiringi dengan sistem pengendalian sosial, yang dapat dilakukan oleh individu terhadap individu lainnya atau dilakukan individu terhadap suatu kelompok tertentu, atau suatu kelompok terhadap kelompok lainnya, atau oleh suatu kelompok terhadap individu. Sistem pengendalian sosial bertujuan mencapai keserasian dan kedamaian antara stabilitas dengan perubahan dalam masyarakat. Sedangkan alat yang digunakan untuk pengendalian sosial dalam hal perlindungan hak konsumen terhadap sertifikasi dan labelisasi produk 
halal pada produk obat-obatan yang paling utama adalah kepatuhan pelaku usaha dan kesadaran konsumen.

Berdasarkan wawancara dengan Siti Nur Azizah, ${ }^{23}$ konsumen berhak mendapatkan perlindungan terhadap produk-produk obat-obatan yang beredar. Masyarakat selaku konsumen berhak dilindungi, namun masalahnya terhadap produk obat-obatan untuk saat ini memang masih banyak yang tidak mencantumkan label halal. Untuk memberikan perlindungan tersebut, maka pemerintah melalui UUJPH memberlakukan kewajiban setiap produsen obatobatan untuk mencantumkan label halal yang akan diberlakukan pada tahun 2019 mendatang. Produsen yang tidak melakukan label halal dikenakan sanksi. Namun yang menjadi permasalahan adalah kendala pemeriksaannya membutuhkan waktu yang panjang untuk mengetahui bahan obat-obatan maupun tambahannya apakah mengandung DNA babi atau tidak, belum lagi adanya kemasan cangkang yang digunakan juga harus diperika bahan bakunya. Bahan tambahan itu perlu dilakukan pemeriksaan lebih dalam disitu ada rekayasa genetik dan ada teknonologi perlu adanya pemeriksaan disitu ada high rise maksudnya sepertinya penyemebelihan itu perlu di uji laboratorium penulusuran atau dilakukan penulusan mendalam yang low rise yang sudah jelas-jelas halal.

Dalam rangka memberikan perlindungan konsumen terhadap ketiadannya label halal pada produk-produk farmasi yang beredar di pasaran, maka menurut penulis diperlukan perlindungan hak yang ideal dalam pelembagaan sertifikasi halal adalah yang dilakukan secara kolektif baik oleh pemerintah maupun masyarakat. Perlu adanya koordinasi lintas kementerian dan lembaga. Namun setidaknya, pelaksanaan perlindungan dan penegakan hukum perlu dilakukan upaya pengawasan oleh pemerintah dapat melalui 3 (tiga) sistem pengawasan, yakni:

1. Sistem pengawasan preventif. Sistem pengawasan ini dilakukan secara dini terhadap produk pangan halal (cakupan produk makanan/minuman yang memerlukan sertifikasi halal cukup luas, salah satunya adalah obat-obatan), antara lain berupa kegiatan pendaftaran. Dengan mengoptimalkan sistem

\footnotetext{
${ }^{23}$ Wawancara dengan Dr. Hj. Siti Nur Azizah, S.H., M.Hum, Op.Cit.
} 
preventif, penyelewengan sertifikasi halal dapat diminimalisir sejak dini. Sehingga harapannya, potensi lembaga penegak hukum dapat berjalan secara maksimal, efektif dan efisien.

2. Sistem pengawasan khusus. Sistem pengawasan khusus ini maksudnya adalah pengawasan aktif terhadap kasus pangan, obatan-obatan dan kosmetika halal yang dapat mengakibatkan dampak yang luas, yaitu tidak saja dalam segi kesehatan tetapi juga dalam segi sosial dan ekonomi. Ketika ditemukan tandatanda yang menunjukkan adanya kasus tertentu penyelewengan sertifikasi dan/atau labelisasi halal di lapangan, maka sistem ini mendorong penegak hukum menanganinya dengan tindakan yang spesifik berdasar pada kekhususan pelanggaran yang dilakukan.

3. Sistem pengawasan insidental. Sistem pengawasan insidental merupakan proses pengawasan yang dilakukan pihak penegak hukum terhadap keamanan dan keselamatan pangan halal yang dilakukan dengan cara inspeksi mendadak (sidak). Memang Pasal 51 UUJPH telah mengatur ketentuan mengenai pengawasan ini, akan tetapi masih memerlukan peraturan perundangundangan sebagaimana ditegaskan dalam Pasal 51 Ayat (2).

Ketiga sistem di atas, selain dilakukan oleh aparat penegak hukum, perlu juga melibatkan peran serta masyarakat dan lembaga yang berkompeten terutama mengenai persoalan halal-haram, representasi mayoritas penduduk muslim, dan sekaligus lembaga yang mendapat pengakuan pemerintah dalam rangka menegakkan hukum UUJPH, upaya perlindungan hukum terhadap konsumen khususnya terhadap ketiadaan sertifikasi dan labelisasi produk halal pada produk obat-obatan. UUJPH juga telah mengatur ketentuan peran serta masyarakat dalam penyelenggaraan JPH sebagaimana ditegaskan dalam Pasal 53 UUJPH. Namun, ketentuan lebih lanjut mengenai tata cara peran serta masyarakat diatur dalam Peraturan Menteri. 


\section{PENUTUP}

\section{A. Kesimpulan}

Berdasarkan uraian analisis di atas, maka dapat disimpulkan sebagai berikut:

1. Ketiadaan label halal pada produk farmasi dikarenakan adanya faktor-faktor yang mempengaruhinya yaitu karena sulitnya mencari bahan pengganti untuk bahan obat karena bahan obat-obatan 90 persen diimpor dari negara lain yang belum ada jaminan kehalalannya. Dalam waktu dekat pihak produsen obatobatan juga mengalami kendala karena harus melakukan penelitian terhadap bahan baku karena adanya kesulitan asal bahan juga memiliki kompleksitas tersendiri sehingga membutuhkan waktu yang cukup lama. Di sisi lain, peralatan yang digunakan untuk proses produksi, lokasi produksi, pengolahan, penyimpanan, pengemasan dan penjualan serta penyajiannya harus dibuat terpisah antara bahan/produk yang sudah bersertifikat halal dan non-halal.

2. Perlindungan konsumen terhadap produk-produk farmasi yang tidak mencantumkan label halal perlu ada 3 (tiga) tsistem pengawasan yaitu preventif dilakukan secara dini terhadap produk pangan halal, antara lain berupa kegiatan pendaftaran. Dengan mengoptimalkan sistem preventif, penyelewengan sertifikasi halal dapat diminimalisir sejak dini. Sehingga harapannya, potensi lembaga penegak hukum dapat berjalan secara maksimal, efektif dan efisien. Sistem pengawasan khusus. Sistem pengawasan khusus ini maksudnya adalah pengawasan aktif terhadap kasus pangan, obatan-obatan dan kosmetika halal yang dapat mengakibatkan dampak yang luas, yaitu tidak saja dalam segi kesehatan tetapi juga dalam segi sosial dan ekonomi. Sistem pengawasan incidental yaitu proses pengawasan yang dilakukan pihak penegak hukum terhadap keamanan dan keselamatan pangan halal yang dilakukan dengan cara inspeksi mendadak (sidak).

\section{B. Saran}


1. Produsen produk farmasi hendaknya dapat melaksanakan ketentuan UndangUndang Nomo 33 Tahun 2014 tentang Jaminan Produk Halal khususnya terkait pencantuman label halal pada produk farmasi.

2. Para ahli farmasi hendaknya bisa mencarikan solusi untuk mencari bahanbahan dan teknologi yang menjawab solusi kehalalannya. Karena, mayoritas penduduk Indonesia adalah muslim. Karena itu persoalan halal harus menjadi pertimbangan dalam produksi obat.

3. Perlu ada upaya sistematis bersama dari pemerintah dan pemangku kepentingan terkait untuk mendorong pembuat produk obat yang halal dan meningkatkan kepedulian masyarakat muslim tentang pentingnya kehalalan produk. Hal ini bertujuan untuk melindungi umat muslim dari mengonsumsi produk yang tidak halal.

4. Dalam kaitannya lembaga yang berwenang melakukan sertifikasi halal, BPJPH harus melakukan sosialisasi terus menerus kepada masyarakat akan pentingnya sertifikasi produk halal, karena bisa saja kesadaran masyarakat masih kurang akan hal ini. Selain itu, pemerintah juga harus mendukung sepenuhnya keberadaan BPJPH ini, sehingga bisa berjalan dan melakukan tugasnya dengan maksimal.

\section{DAFTAR PUSTAKA}

\section{A. Buku}

Albaghdadi,Abdul Rahman.Babi Halal, Babi Haram.(Jakarta: Gema Insani Press, 1989).

Al-Qardhawi, Yusuf.Halal Haram Dalam Islam, terjemahan Abu Hana Zulkarnain dan Abdurrahim Mu'thi, cet. 1. (Jakarta: Akbar; Media Eka Sarana, 2004).

Ansel, H.C. Introduction to Pharmaceutical Dosage Forms.(Philadelphia: Lea \& Febiger, 1981).

Badan Perencana Pembangunan Nasional, Badan Pusat Statistik dan United Nations Populations.Proyeksi Penduduk Indonesia: 2010-2035. (Jakarta: BPS, 2013). 
Bagian Proyek Sarana dan Prasarana Produk Halal Direktorat Jendral Bimbingan Masyarakat Islam dan Penyelenggara Haji.Panduan Sertifikasi Halal. (Jakarta: Departemen Agama RI, 2003).

Bagian Proyek Pembinaan Pangan Halal Ditjen Bimas Islam dan Penyelenggara Haji, Pedoman.

Dahlan,Abdul Azis.Ensiklopedi Hukum Islam.(Jakarta: Ikhtiar Baru Van Hoeve, 1996).

Burhanuddin.Pemikiran Hukum Perlindungan Konsumen dan Sertifikat Halal. (Malang: UIN Maliki Press, 2011).

Departemen Kesehatan Republik Indonesia.Kebijakan Obat Nasional. (Jakarta: Departemen Kesehatan Republik Indonesia, 2005).

Girindra, Aisjah.Pengukir Sejarah Sertifikasi Halal. (Jakarta: LP POM MUI, 2005).

Hadi, Sutrisno. Metodologi Reseacht. (Yogyakarta: Andi Offset, 1989).

HS, Salim dan Erlies Septiana Nurbani.Penerapan Teori Hukum Pada Penelitian Tesis Dan Disertasi.(Jakarta: RajaGrafindo Persada, 2016).

Marzuki, Peter Mahmud. Penelitian Hukum, Cetakan ke-2. (Jakarta : Kencana, 2008).

Muhammad,Abdulkadir.Hukum dan Penelitian Hukum.(Bandung: Citra Aditya Bakti, 2004).

Nasution, Az. Hukum perlindungan Konsumen; Suatu Pengantar.(Jakarta: Diadit Media, 2006).

Soekanto,Soerjono.Pengantar Penelitian Hukum.Cetakan ke3.(Jakarta:Penerbit UI Press, 1986).

Shidarta.Hukum Perlindungan Konsumen Indonesia. (Jakarta: PT Grasindo, 2006).

\section{B. Peraturan Perundang-Undangan}

Undang-Undang Nomor 7 Tahun 1996 tentang Pangan; Lembaran Negara Tahun 1999 Nomor 131, Tambahan Lembaran Negara Nomor 3867). 
Undang-Undang Nomor 8 Tahun 1999 tentang Perlindungan Konsumen, (Lembaran Negara Tahun 1999 Nomor 42; Tambahan Lembaran Negara Nomor 3821).

Undang-Undang Nomor 36 Tahun 2009 tentang Kesehatan, (Lembaran Negara Tahun 2009 Nomor 144; Tambahan Lembaran Negara Nomor 5063).

Undang-Undang Nomor 33 Tahun 2014 tentang Jaminan Produk Halal, (Lembaran Negara Tahun 2014 Nomor 295;Tambahan Lembaran Negara Nomor 5604).

Peraturan Pemerintah Nomor 69 Tahun 1999 tentang Label dan Iklan Pangan; Lembaran Negara Tahun 1999 Nomor 131; Tambahan Lembaran Negara Nomor 3867)

\section{Jurnal}

Aminuddin, Muh. Zumar. "Sertifikasi Produk Halal: Studi Perbandingan Indonesia dan Thailand".SHAHIH - Vol. 1, Nomor 1, Januari - Juni 2016.

Evianto,Hadi. "Hukum Perlindungan Konsumen Bukanlah Sekedar 'Keinginan' Melainkan Suatu 'Kebutuhan', Hukum dan Pembangunan, 1986: 8 tahun ke XVI, Desember 1986.

Nasution,Az. "Sekilas Hukum Perlindungan Konsumen", Hukum dan Pembangunan, 1986: 8 Tahun ke XVI, Desember 1986.

Putriana,Norisca Aliza.“Apakah Obat yang Kita Konsumsi Saat Ini Sudah halal?"Majalah Farmasetika, Vol.1 No.4, 2016.

Shofie,Yusuf. "Jaminan Atas Produk Halal Dari Sudut Pandang Hukum Perlindungan Konsumen" Jurnal Syariah 3, November 2015.

\section{Artikel/Makalah/Internet}

Anonim."Manfaat Viostin DS Bagi Tubuh - Rematik dan Asam Urat".(OnLine). https://manfaat. co.id/manfaat-viostin-ds.(7 Februari 2018).

Balai Besar Pengawasan Obat dan Makanan Mataram, "Hasil Pengujian Sampel Uji Rujuk Suplemen Makanan”, Mataram, 5 Desember 2017.

Depkes."Hanya Tiga Jenis Obat Yang Mengandung Babi”.(OnLine).http://www.depkes.go.id/article/view/2014430001/hanya-tigajenis-obat-yang-mengandung-babi-.html.(9 Maret 2018). 
Editorial Team, "Viostin DS dan Enzyplex Lolos Uji LPPOM MUI karena Negatif DNA Babi”, (On-Line).https://kumparan.com/@kumparanbisnis/viostin-ds-dan-enzyplex-lolos-uji-lppom-mui-karena-negatifdna-babi?ref=rel.(5 Februari 2018).

Kementerian Kesehatan RI (Tim Redaksi). "Gambaran Kesehatan Lanjut Usia di Indonesia", Bulitin Jendela Data dan Informasi Kesehatan, Semester I, Tahun 2013.

Mansyur, Ali dan Muhammad Nursyamsi."Ketika Badan POM Kebobolan Produk Mengandung Babi Lagi”, (OnLine).http://www.ihram.co.id/berita/nasional/newsanalysis/18/02/01/p3fkj44-40-ketika-badan-pom-kebobolan-produkmengandung-babi-lagi.(6 Februari 2018).

Purba,Victor. "Pokok-pokok Pemikiran tentang Aspek Yuridis Perlindungan Konsumen dalam Mengantisipasi Perkembangan Industri di Indonesia", makalah pada Pertemuan Organisasi-organisasi Perlindungan Konsumen, diselenggarakan YLKI, di Jakarta, Hotel Sabang, 18 Februari 1998, tanpa halaman.

Samsul,Inosentius.Perlindungan Konsumen: Kemungkinan Penerapan Tanggung Jawab Mutlak (Disertasi) (Jakarta: Program Pascasarjana Fakultas Hukum Universitas Indonesia, 2003/2004, Cet.ke-1).

\section{E. Kamus}

Poerwadarminta,W.J.S. Kamus Umum Bahasa Indonesia, Edisi ke-3. (Jakarta: Balai Pustaka, 2006). 